\title{
Historical Reconstruction as a New Space of Patriotism for Youth
}

\author{
Al'bina Raisovna Garifzianova ${ }^{1} \&$ Liliya Gabdelvalievna Nasyrova ${ }^{1}$ \\ ${ }^{1}$ Elabuga Institute of Kazan (Volga region) Federal University (KFU), Russia \\ Correspondence: Al bina Raisovna Garifzianova, Elabuga Institute of Kazan (Volga region) Federal University \\ (KFU), Kazanskaya st., 89, Elabuga, Tatarstan Republic, 423600, Russia.
}

Received: November 1, 2014 Accepted: December 23, 2014 Online Published: March 16, 2015

doi:10.5539/ass.v11n7p183

URL: http://dx.doi.org/10.5539/ass.v11n7p183

\begin{abstract}
In recent years Russia has witnessed a massive expansion of national-patriotic youth associations. Following the decades of officially de-ideologised politics and withdrawal of the state from the discussion of national identity young people turned towards various informal interpretations and enactments of Russianness. The article investigates one particular case of such enactment. It describes cultural, economic, and political practices of the Orthodox military-patriotic club "Rus" based at the Saint Vladimir church. The club is a scene uniting members of various subcultures. It was formed as a place for young people interested in history, and reconstruction of historical military equipment, and a platform to discuss and promote Russian nationalist ideas. The research, based on participant observation of the club's activities, and interviews with its members, analyses internal organisation of the club, ideological orientations of its members, and relations with other similar organisations, notably, with the club of Orthodox bikers. The article demonstrates how in Russia a space of a religious institution becomes a platform where subcultural identities are discussed and negotiated.
\end{abstract}

Keywords: observation, reconstruction, subcultures, patriotism, youth, subcultural identities, religious institution, case-study

\section{Introduction}

Research of youth environment and youth subcultural groups in modern stage of society development is a topic of special interest. It is caused not only by the fact that youth problems have always attracted state institutions but also by topical character of youth environment research in the context of today situation in the world in general. For many scientists youth research is related first of all to defining problems of youth space, scientists spoke and write about the youth in the context of youth problems (Omel'chenko, 2004). Analysis of everyday life of the youth, cultural practices and interests we consider to be more practical for understanding of today young people. Such researchers as E. Omel'chenko, H. Pilkington, I. Gololobov, A. Garifzianova (Pilkington et al., 2010; Garifzianova, 2011; Omel'chenko, 2012; Gololobov, 2014) and many others study youth not from the point of view of ideology and politics but mainly from the point of view of understanding of cultural practices and everyday interests. In the present article the author tried to analyze life strategies, cultural interests and practices of a certain youth group not from the point of view of cub-cultural theories, but from the point of view of understanding that today different representatives of different youth subcultures identifies themselves with a certain interests and scenes including patriotic ideas. I mean orthodox military and patriotic club "Rus " situated on the territory of temple. This unified youth group is a perfect demonstration of the main idea of the research that is that groups of different youth join around one cultural idea or scene. In this case the group was supported by representatives of such social institution as church. Informal name of this group is the club of historical fencing. There are numerous works about historical reconstruction, including the works of such authors as V. V. Khabarov (2006), D. A. Tarasov (2013), E. Zabotkina (2010), V. Sobolev (2014) and others but most of the works has publicistic rather than scientific character.

\section{Methods}

Results of research project "Innovative potential of Russian youth: solidarity, active position and civil responsibility" have been analyzed in this work. Case study is the main method of the research (Gotlib, 2002), that presupposes involved observation of studied environment (during a month in 2012). In this case the subject of research is youth solidarity (club). Besides, research journal has been regularly filled in during "field" stage that allowed reconstructing the full picture of youth scene under research. It is the most relevant and practical 
method to understand the essence of researched youth solidarity. Participants of historical reconstructions were interviewed in 14 semi-structured interviews. Researches focused on the one, a net of relationships with other groups and communities had formed around.

\section{Results}

Specific of this youth group is combination of cultural practices and interests of seemingly different spheres: religion, interest to history, religiousness, patriotic ideas and subcultural strategies.

The club was formed in February, 2001 by rector of temple. According to one of the club leaders, "management shares our views on the history" and provided premise without rent (see Note 1). The club situated in basement room of the forge in the territory of temple. Informal mane of this group is club of historical fencing.

Research journal (11.11.12) "Roma thinks the name of the club doesn't matter. But name "Rus" may go in for clergymen. The best name according to one of informants is "Bear's lair". Officially the club is orthodox and patriotic...".

Historical fencing is most hard type of historical reconstruction according members of this movement. "To wear armour not to mention fighting in it one needs to be a good sportsman and to be tough". There are several clubs where such fighters are training in Ulyanovsk, and they are different in their internal atmosphere and essence. There are some formal unions that actually turned into groups of the Center of Children Creativity (for example, club "Flint"), there are clubs with experience and long history (clubs "Squad", "Knight" or "Lynx"). And then such club as "Rus "” was formed. On the one hand, it happened relatively not long ago, and it has rather informal character, and on the other hand, it has the history of continuity. Club "Rus " was formed mainly due to its leader who is the successor of traditions of the other historical club. This informal group passed the way from personal interest to historical reconstruction and fencing to forming the club under orthodoxic church in semi-formal level. Heretofore the leader and the close friends consider themselves as radical nationalist part of youth groups (see Note 2).

Main types of cultural activities and everyday practices are physical training (special training), the basics of hand-to-hand fight, fencing itself, making armour of Slavs (13-16 century), armour of the Early Middle Ages (9-14 centuries). But binding dimension of activity was communication with each other on the base of patriotic topics and interest to history. One of respondents said about the main practices in club "Besides training we just stay there, spoke, make something, for example, just spoke in a small basement room, perhaps it was just a coincidence that people were psychologically compatible, than we went together for show, a sort of cultural events... birthdays together" (from the interview with Int_2_D (Rus).

It was a special atmosphere in club, everybody describes it as "family, warm, home". Most of club members noted ease of communication, described the team as afamily. Of course, club leader could create such an atmosphere. Besides, it is worth noting, that historical fencing took rather a second place. According to one of informants, "it was a get-together club. They came, roughly speaking, when Sashka is in one mood, he made them work hard, another time Sashka is in the other mood and he made them work very hard, and third time they came and just had a beer drunk and some armour making. No system" (from interview with Int_3_R (Rus). Communication took first place, the so called "conversation" that didn't stop even during training (for example, press-up). “... about 80 people have passed through our club. Because they came and gave up. It was training at first, than we sat and discuss something. Sasha wrote the Charter. We sat, sewed shirts... you know, white shirt meant adolescent... we sewed caps, trousers, too... there were always these sittings and discussions after training. We always discussed something, Sasha introduced a topic..." (from the interview with Int_7_An (Rus).

There were a certain rules of conduct in club, because at first it was situated on private territory. Trust and respect were the matters of great importance. Trust was supported by a word of the other club members. For example, when in the weekends too many people started to visit club the leader introduced a rule: only those were allowed who had recommendation of a member of club that meant that this member authorized adequate behaviour of the new member. When a member was late without sound reason or a phone call all members pressed-up while waiting. As a girl member said, "the process itself was attractive. We were like a family... even say, you came, knocked off two parts of your helmet, and, say, it is so cool, everybody support you, it became a sample" (from the interview with Int_7_An (Rus). The fact that the club was situated in apartment house also helped development family atmosphere, closeness and trust. "Everyone knows our family, asks: how mom doing? Ksiusha?.. so much want to visit and find out... it really couldn't pass without noticing, mom, it's cold in basement room, she brought us pancakes or stewed fruit, just have it... Ksiysha was brought up by the club actually" (from the interview with Int_7_An (Rus). 
In 2010 the club practically messed up "the leader changed the way of life (see Note 3), we had no premise, gave up meeting in the basement room, out small garden, our territory had overgrown... there was a chin-up bar and training ring there..." (from the interview with Int_7_An (Rus). The leader started to go in for strikeball (see Note 4) where he met informant $\mathrm{T}$. who was the member of Resistance movement (with nationalistic character) (see Note 5). In 2011 rector of the temple proposed him to launch military and historical club under temple. There was also a forge there. Main members of the group worked in this forge and they led orthodox patriotic club. Besides in this year the leader entered organization named Russian bikers "Night Wolves" and became official tattoo-maker for the club. It was the end of the first stage of young people joining around historical fencing and the beginning of the second stage related with such location as forge under orthodox temple.

\section{Discussions}

The club "Rus" is located in basement premise the same with temple forge. Before entering the forge (see Note 6) it is necessary to pass almost all the temple territory. "As a matter of fact all buildings forms a sort of a circle, with unfinished foundation ditch and dump in the middle. Forge is to the right in the same direction as temple itself. Forge area is big, it is separated into three zones: forge (forge, sledge-hammer and stove), the zone were members have tea with cupboards with armour, tape-recorder and a space where fights and training go on. The basement room is not heated, but there is electric power. It is difficult to train here in winter. Traditional practice in forge is tea and "discussion". Water is being boiled regularly without stopping. All the forge is filled with smoke and ashes of the stove. There are numerous engineering tools in the forge. There are even two home gyms and a weight here..." (from research journal 13.11.12). Combination of professional space - the forge and informal - the club is reflected in the atmosphere in the basement room: helmets, chain armours, iron plates for bowls, swords, feedstock for forge. Club "Rus" has an advantage from the point of view of resources according to members of other clubs, "to start with, without taking in account accumulated things and so on, "Rus" has greater possibilities. First of all the workshop, it has by order of magnitude greater possibilities than "Knight". They have furnace and tools. An even the territory itself, is a sort of stimulates..." (from the interview with member of the club "Knight" (Int_13_N (Vityaz).

The other practice in the club is alternating training: one day physical training, mastering the technique, another day - preparation of armour and getting ready to tournaments.

So, this group unites completely different young people with different interests and practices. Central and public interest that joins different communities is interest to history and consequently interest to historical fencing. There are young people interested in history who reconstructs everyday life of a certain age; these young people usually go in summer on different festivals. The other category of those who are interested in history pay no so much attention to the relevance of a suit or armour to a certain historical period but interested in the process of fighting itself. These young people pay slight attention to authenticity of a suit, "one of the members said that there are a number of clubs in the city but image of members from U lyanovsk is very low and they are called as Nikita said goblins. The reason is dull suits. Only fighters from U'lyanovsk can fight with shields, helmets in the suit with rusty elbow pads and in trainers. Trainers and plastic in the armour are terrific as he said. You cannot do like this. If you reconstruct you should have footwear relevant to the period. He himself makes footwear of leather..." (from research journal (13.11.12).

There are people engaged in historical reconstruction for whom the armour including the process of its making plays more important role:

Interviewer: I caught. Did you want a real suit?

Respondent: Yes, as relevant as possible, not to have a sort of faugh! Our city has already a sort of bad reputation... goblins. We came on a contest, everybody see and than faugh!, goblins. They point the finger... I mean it is a sort of bad trend already and I didn't want to keep it. So I work step by step. I am often abused for being slow. My armour was not ready to the competition, so I didn't fight, because I prepared it, put on, and saw creases here, you see, here in this way and here in that. I cannot fight in this way, can I? And almost no time left is was 10 p.a., Friday. So I have nothing to do but decline..." (from the interview Int_13_N (Vityaz).

Possibility to make or buy armour affects forming interest to history. Lack of experience and possibility to make armour themselves (see Note 7) force young people to fight in armour of the club (see Note 8), so one reconstruct such period of history that is relevant to armour he managed to find.

But it is necessary to note that besides interest to history, mainly military clubs form sporting atmosphere around that attracts different people. Historical fencing is a sport with championships in Russia and in the world and it requires force and hardiness and training as any sport. "Reconstruction of historical events on one hand is being 
promoted by state, municipal authority and on the other hand it is supported and developed on informal base... There are informal historical reconstructing clubs that became popular with youth as a form of entertainment..." (Zabotkina, 2010).

Clubs attracts existing or former sportsmen (see Note 9). The absence of effective mechanisms of youth socialization in today society and possibilities for self-realization causes the search of the forms of self-realization outside social field, including some forms of risk behaviour, according to Zharkov G. V. (2007). Traditional perception of "masculine behaviour" as a set of forceful and authoritative male roles the content of which should be demonstrated allows the choice of risk and extreme to find numerous points of contact with other communities and groups. Besides historical fencing as a space of risk and competitiveness attracts people who may not be interested in history although there are a lot of those who are really interested, but look for the process of physical "discharge": "fighting is at first physical training, at second it develops coordination, and at third I think everybody feel it a sort of psychological pleasure of hitting opponent, or of hitting the target in shooting, and hitting the opponent is something of the same kind" (from the interview with Int_2_D(Rus). Such sphere as sport is a way to satisfy the need to competition that is one of important features of development of male identity represented also with demonstration of force and hardiness (see Note 10).

One of the key joining dimensions of the club is patriotic ideas, the history of victories as manifestation of military spirits, xenophobic ideas and nationalistic views. Xenophobic ideas are often related to demonstration of extremes (Gromov, 2007). Almost all the respondents revealed their xenophobic ideas:

Interviewer: Who are "churki"?

Respondent: They are not Caucasian. They are buck and imbeciles came from the mountains. These are Azerbaijanians and Chechens because they behave themselves in improper way...".

Almost everybody demonstrated their concern about the situation in the country, spoke what does it mean to love motherland and how it should be manifested. "I think the one should love his motherland, after all. But it is motherland that one should love not the state. It is great difference. Completely different things. Because the state is one people and motherland is the other people. Motherland is a component of a soul. Well, some people think that motherland is where they feel good. But mu motherland is Russia. Patriotism is nothing without nationalism. Because patriotism is love to the country not to the state, just country, to Russia, for example, and nationalism is love to one's nation..." (from the interview with informants T. (Int_6_Tiler (K).

Respondents often ties patriotism, xenophobic ideas and healthy way of life together. They stressed that one should start with oneself. "Speaking about patriotism, all these "sofa experts", when a guy sits before the computer and hold forth, it is bullshit. Patriotism should start with oneself. One should start with oneself, improve oneself, at least don't leave litter about in streets" (from the interview with respondents from the club "Knight" (Int_13_N(Vityaz). It is difficult to separate these three vectors - patriotism, nationalism and principles of healthy way of life, they are being mutually translated and add each other. Nationalistic ideas attract members from the other solidarity groups and communities with ideology close to orthodox, patriotism and nationalism (see Note 11). "Nationalism is a core for the soul, for oneself. If I call myself a Russia nationalist I must be relevant, I should go in for sport, I should not drink, smoke, I should know history, love country, respect women" (from the interview with T. (Int_10_Tiler 2(K).

In general nationalistic ideas are closely tied with sympathy for paganism. Sympathy to paganism is not being only spoken about, young people make tattoo: "He also show tattoo that S. make on the leg. Describe what has Vanya on his back. S. and he has Slav symbol black sum on an elbow. Said that it is a pagan symbol that resembles swastika. It has 12 ends. He believes in the power of the symbol. It makes me more confident, he said. Why pagan symbol? Because it is the faith of ancestors, orthodoxy was imposed" (from research journal 22.11.12).

Paganism does not prevent the club to have the name orthodox patriotic military historical club "Rus"”. It is explained by the fact that paganism is native Russian faith, it is the symbol of ideal past it is "tribute of respect to ancestors that fight for radiant future". Sympathy to paganism is also tied with the views of a man as a fighter: "man is fighter in his essence, in the sight of God. He should protect his family. His land. There are people who may cause harm in peacetime. Man, he is a getter that means that it should be the core of a fighter. If a man is tender and corny, there will be no results" (from the interview with T. (Int_6_Tiler(K).

Attitude to religion is extremely inconsistent. On one hand the club is situated on the territory of temple and club leader is Orthodox believer, on the other hand everybody declare critical attitude to church as an institution. Other respondents said that they have slight idea of church ceremonials. Church for them is "an institution, it 
was made to give order for all these things, to avoid a kind of scattering, for order, one should do this or that" (from the interview with Int_13_N (Vityaz).

Another important joining dimension for youth is music (Brown, 2004). According to Simon Frith, young people see in music the space for realization of their possibilities, they turn to music for support and also to relax, but most of all they are interested in artistic aspects of music - the complexity of music constructions or poetics of texts (Frith, 1983). Music preferences traditionally play leading role in any group. "Our club was not so to say informal get-together, but near a subculture of the kind, music was a sort of welcomed. I mean nobody listen to Shanson, Music at large... about rock it was all but lyric" (from the interview with Int_2_D(Rus).

One more characteristic feature of grouping in club "Rus " was interest to history and literature. All the members are constantly reading: they have books downloaded to their phones, e-books, somebody are still reading paper books. Leader reads a lot of fiction and special literature on history that allows for example to reconstruct authentic armour of English king Edward Black Prince. One of informants prefers to read Chekov's short stories. "I read collected short stories. Time is just there, and I realize that people thought in the way just we do, they have the same vices, the same idee fixe, all the same. And he communicates it graphically and precisely. They say he is a surgeon. Some time Pelevin impressed me, but he actually writes without a link to reality, but some moments a sort of scratch out interest thoughts in general" (from the interview with Int_2_D (Rus).

\section{Conclusions}

So, researched youth scene is not limited to one sphere of historical fencing, and includes representatives of the youth with nationalistic ideas, people of industrial arts (see Note 12) who are interested in history, sportsmen as well as music groups. Common core represented in value milestones was important for community. It is also represented in explaining choices, practices and interests: it is interest to historical fencing, to making armour, blacksmith's work, sympathy to paganism, to history, music and of course nationalistic ideas, in some extent rejection of consumption ideology - attitude to money, patriarchal views, attitude to the state which is on the one hand critical and on the other hand sympathetic to strong power.

Considering understanding of solidarity that may cover different youth communities and include different subcultural entities one may say that participants involved in analyzed youth scene are joined by the same practiced life style. Making preliminary conclusion, one may separate the following key ideas common for this solidarity:

- Music (mainly hard rock)

- Patriotism (via interest to history, to faith of ancestors)

- Rejection of consumption

- Healthy way of life. (Figure 1)

Typical features of this solidarity are also that it is mainly male group with dominating interest to power sports, to physical work (a will to make something oneself). It is also necessary to point out one common vector of the group - independent character of all organized activities: this group initiated different types of activity independently of any organizations or institutions, it is the group created "from downside", not initiated "upside down".

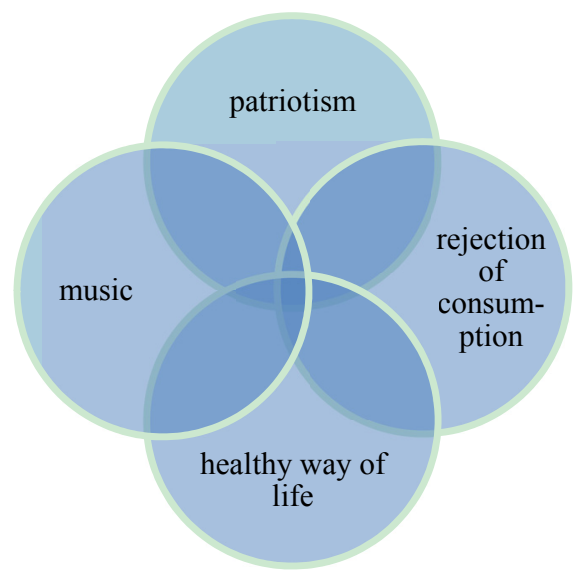

Figure 1. 


\section{Acknowledgments}

The project was carried out in the scope of the Program of Fundamental Research in 2012 with Center for Youth Studies at the National Research University High School of Economics (St.-Petersburg) and Scientific Research Center "Region" (Ul'yanovsk).

\section{References}

Brown, T. S. (2004). Subcultures, Pop Music and Politics: Skinheads and "Nazi Rock" in England and Germany. Journal of Social History, 38(1), 157-178.

Bykov, A. (2014, September 29). Historical reconstruction. Problems and solutions. Retrieved September 30, 2014, from http://www.goldenforests.ru/library/misc/bykov_rekonstrukciya.html

Frith, S. (1983). Sound Effects. Youth, Leisure, and the Politics of Rock 'n 'roll. London: Constable.

Garifzyanova, A. (2013). Research Emotions in the Field: The View from the Other Side. World Applied Sciences Journal, 27(8), 1079-1082. http://dx.doi.org/10.5829/idosi.wasj.2013.27.08.13734

Garifzyanova, A. R. (2011). Subcultural resources and practices of youth as overcoming of social restrictions (based on materials of ethnographical research of skinhead company). The journal of social policy research, 9(3), 339-364.

Gololobov, I. (2014). Punk in Russia: Cultural Mutation from the 'Useless' to the 'Moronic' (with Hilary Pilkington and Yngvar B. Steinholt). London: Routledge.

Gotlib, A. (2002). Introduction to sociologic research. Samara: University of Samara.

Gromov, D. (2007). Youth: extreme construction. Man's collected works. Man in extreme situations, 3. 67-84. St.-Petersburg.

Gudkov, L., \& Dubin, B. (2005). Svoeobrazie russkogo natsionalizma. Pro et Contra, 2, 6-24.

Hutchinson, J., \& Smith, A. D. (Eds.). (1994). Nationalism. Oxford, UK: Oxford University Press.

Khabarov, V. (2006). To reconstructors about reconstruction (pp. 8-11). Reconstruction of historical costume. Kazan.

Nikolski, A. (2014, October 8). Methodological problems of historical reconsruction. Retrieved October 9, 2014, from http://www.newchrono.ru/prcv/doklad/methodology.htm

Omel'chenko, E. (2004). Youth: open question. Ul'yanovsk: Simbirskaya kniga.

Omelchenko E. L., \& Pilkington H. (2013). Regrounding Youth Cultural Theory (in Post-Socialist Youth Cultural Practice). Sociology Compass, 7(3), 208-224.

Omelchenko, E. (2012). How to teach to love motherland? Discursive practices of patriotic education of youth. What motherland begins with: youth in the labyrinths of patriotism. Ulyanovsk, 263-306, ISBN 978-5-88866-446-9

Pilkington, H., Omel'chenko, E., \& Garifzianova, A. (2010). Russia`s skinheads: exploring and rethinking. London: Routledge.

Sobolev, V. (2014, October 13). Problems of study of early stage of ancient Russian funeral culture in the west of Novgorod land. Retrieved October 14, 2014, from http://www.nwae.spbu.ru/?0-210

Tarasov, D. (2014, September 30). Historical reconstruction. Development problems. Retrieved October 3, 2014, from http://samlib.ru/t/tarasow_d/recon_problem.shtml

Zabotkina, E. (2010). Historical reconstruction movement as a part of the way of life of Russian youth. Internet-conference Children and youth. Retrieved from http://www.ecsocman.hse.ru/text/33373330/

Zharkov, G. (2007). Risky character of manhood: The role of gender factors in development of behavorial risks of youth. Man's collected works. Man in extreme situations, 3, 66-76. St.-Petersburg.

\section{Notes}

Note 1. Rent was about 20,000 Rubles a month in 2012. It should be noted that there are many premises on temple territory that are leased to businesses, for example to plastic windows factory, motor-car service, etc.

Note 2. Still call themselves nationalists. 
Note 3. Marry.

Note 4. It is command extreme game with low power pneumatic guns.

Note 5. Informant T. - one of the members of skinhead team in 2009.

Note 6. Both guys themselves and other members of historical fencing call this place forge.

Note 7. Note related to Russian name of armour (not interpreted into English).

Note 8. For example, many members of the club "Knight"fighted in the tournament November 17, 2012 Mongol armour made of leather, as one of informants said, "they made it once, maybe the leather was cheap". These armoursis the property of club. Some guys a sort of lease armour from club or a person.

Note 9. For example, one of them is former champion in kickboxing. The other informant is trainer of the other club having come from sport.

Note 10. Although there are girl members who gain respect of fighters-men and they also took part in fights there are a few of them.

Note 11. For example, the Club of Russian Bikers is friendly organization for club "Rus", and "Rus" leader is official member of the Club of Russian Bikers and he is called official tattoo-maker of bikers.

Note 12. Most young people had joined independently, from downside due to the interest of blacksmith's work. Many of them, including the leaders of club "Rus" work as working people (mount children game zones in summer), go in for blacksmith's work, iron.

\section{Copyrights}

Copyright for this article is retained by the author(s), with first publication rights granted to the journal.

This is an open-access article distributed under the terms and conditions of the Creative Commons Attribution license (http://creativecommons.org/licenses/by/3.0/). 